\title{
Scottish landform examples 45: Sgriob na Caillich: a landslide-sourced medial moraine on the Isle of Jura
}

Colin K. Ballantyne ${ }^{\mathrm{a}}$ and Alastair G Dawson ${ }^{\mathrm{b}}$

aSchool of Geography and Sustainable Development, University of St Andrews, Fife, UK;

${ }^{b}$ Geography, School of Social Sciences, University of Dundee, Dundee, UK

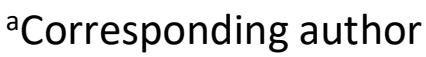

email: ckb@st-andrews.ac.uk

ORCID: Colin K Ballantyne: id http://orcid.org/0000-0002-6044-9198

Main text only: 2967 words

Full document including title, abstract, references and captions: 4430 words 


\section{ABSTRACT}

Medial moraines deposited by former glaciers and ice sheets are rare in Scotland. The most prominent example is the Sgriob na Caillich moraine, which consists of two to four parallel belts of angular quartzite boulders that extend northwestwards for over $3.5 \mathrm{~km}$ from the SW flank of Beinn an Oir on the Isle of Jura. The boulder belts extend to within $300 \mathrm{~m}$ of the present coastline, where they are truncated by a low bluff and raised marine terrace. The source of the moraine coincides with bedrock gullies and cliffs that represent the scars of former rock-slope failure(s), indicating that the moraine debris was sourced by one or more rockfalls or rockslides onto the ice surface after Beinn an Oir had emerged from the thinning ice cover as a nunatak. Exposure dating of boulders on the moraine indicate that it formed at $16.6 \pm 0.8 \mathrm{ka}$, consistent with the timing of ice-sheet retreat in this sector. The alignment of the moraine indicates ice-margin retreat to the SE; as regional ice-sheet retreat across the adjacent offshore shelf was to the NE, this anomaly implies that a residual icefield became stranded on Jura during ice-sheet retreat.

\section{KEYWORDS}

Medial moraines; rockfall; rock-slope failure; last Scottish Ice Sheet; Isle of Jura

\section{Introduction}

The term medial moraine is used to describe a belt or ridge of bouldery debris aligned in a down-ice direction on the ablation zone of a glacier or ice sheet. Although medial moraines on glacier surfaces sometimes take the form of prominent ridges several metres high, their apparent thickness is often illusory: the debris cover retards melting of the underlying ice, so such ridges consist of a core of ice overlain by a thin cover of debris. Medial moraines form in three ways. Some develop at the confluence of two valley glaciers through merging of lateral moraines (e.g. Smiraglia, 1989). Others form from emergence in the ablation zone of concentrations of debris that have been transported englacially or subglacially from ice-marginal or subglacial sources farther up-glacier (e.g. Small et al., 1979; Small, 1987; Vere \& Benn, 1989; Hambrey \& Glasser, 2003; Bennett \& Glasser 2009). Finally, some owe their origin to landslides that have deposited boulders directly onto the ablation zone of a glacier, providing a source of debris that becomes elongated in a down-glacier direction during extensional, converging ice flow (Eyles \& Rogerson, 1978; Benn \& Evans, 2010). Although large, high-energy rock avalanches onto glaciers tend to spread runout debris widely across the ice surface (Deline et al., 2015), smaller rockfall and rockslide events result in accumulation of debris at glacier margins, thus forming a source of coarse sediment that is progressively transported down-glacier to form a narrow supraglacial medial moraine.

Because most medial moraines comprise only a thin cover of supraglacial debris, their potential for preservation and recognition after deposition in the proglacial zone is often limited. On proglacial floodplains they are frequently dismembered by migrating meltwater rivers. In 
other cases, the debris covering a steep-sided ice-cored medial moraine ridge rolls, slides or flows down the ridge flanks and is spread over the ice surface near the glacier terminus, so the debris is no longer concentrated within a confined band. In many locations the debris cover may be too thin to be distinguishable from the surrounding bouldery glacial deposits. Where medial moraines do survive deposition, they often form linear belts of boulders crossing the proglacial zone, or low, subdued bouldery ridges aligned in the former direction of ice flow (Evans \& Twigg, 2002; Bennett \& Glasser, 2009). The deposition of large medial moraine ridges during glacier thinning and retreat occurs only where the debris cover is unusually thick or the debris extends deep within the ice (Anderson, 2000).

Related to medial moraines are erratic trains, which form where the transported debris is of a different lithology to that of the terrain on which it is deposited. Erratic trains form broad, often discontinuous or divergent belts or spreads of scattered boulders, but typically lack surface expression as a continuous ridge or ridges after deposition. Like medial moraines, however, they may be sourced by major rock-slope failures, the classic example being the Footslopes erratic train in Alberta, which extends intermittently for $580 \mathrm{~km}$ southeastwards from its source at the site a major rock avalanche in the Rocky Mountains (Jackson, 2017).

Reported examples of medial moraines in Scotland are rare. They include the Strollamus medial moraine on Skye (Small et al., 2012; Ballantyne et al., 2016a) and a few that have been mapped inside the limits of the mountain glaciers that formed during the Loch Lomond Stade of 12.9-11.7 ka (e.g. Sissons, 1977). By far the most outstanding example of a Scottish medial moraine, however, was deposited during the thinning and retreat of the last Scottish Ice Sheet, on the Isle of Jura in the Inner Hebrides. Known as Sgriob na Caillich (the Old Woman's chute or, more colourfully, the Witch's chute) this descends northwestwards from the foot of the highest of the three mountains known as the Paps of Jura for a distance of over $3.5 \mathrm{~km}$ (Figure 1) and was first described in detail by Dawson (1979a).

\section{The Paps of Jura}

The Paps of Jura $\left(55.87^{\circ}-55.90^{\circ} \mathrm{N}, 05.95^{\circ}-06.02^{\circ} \mathrm{W}\right.$; Figure 2) comprise three mountains, Beinn a'Chaolais $(733 \mathrm{~m})$, Beinn an Oir $(785 \mathrm{~m})$ and Beinn Shiantaidh $(757 \mathrm{~m})$. These mountains and the adjacent terrain are underlain by massive fine- to medium-grained Dalradian quartzites that dip east-southeast at $25-40^{\circ}$ and are locally intruded by doleritic dykes (Anderton, 1977, 1985). During the Last Glacial Maximum, Jura formed part of the onset zone of the Hebrides Ice Stream, a major artery of the last ice sheet that flowed over $220 \mathrm{~km} \mathrm{WSW}$ from Jura across the Sea of the Hebrides to terminate at the shelf edge at 26.7-25.9 ka (Dove et al., 2015; Callard et al., 2018). At this time the Paps of Jura were completely over-ridden by glacier ice, though evidence of glacial erosion occurs no higher than $\sim 660 \mathrm{~m}$ OD (Ballantyne, 1999), suggesting that the ice occupying the highest ground may have been cold-based, frozen to the underlying substrate and hence capable of only limited erosion. Much of the Sea of the Hebrides was deglaciated by $\sim 20.0 \mathrm{ka}$, and by $17.5-16.5 \mathrm{ka}$ the retreating ice margin straddled the fjords, islands and peninsulas of the western seaboard of Scotland (Small et al., 2017). The alignment of striae indicates final movement of ice around the Paps of Jura to the WNW or NW. Moraine ridges south of Beinn an Oir and in particular near Loch an t-Siob provide evidence for 
a period of limited local glaciation, but it has not been established whether these moraines represent oscillations of a residual ice mass stranded on Jura following ice-sheet retreat, or deposition at the margin of a glacier that formed on the island during the Loch Lomond Stade. Following ice-sheet deglaciation, all three mountains sourced catastrophic rock-slope failures. The timing of five of these landslides has been established through cosmogenic ${ }^{10} \mathrm{Be}$ exposure dating (TCN dating) of rockslide runout debris: the results indicate that all five landslides occurred between $15.4 \pm 0.9 \mathrm{ka}$ and $13.7 \pm 0.7 \mathrm{ka}$, and thus within about three millennia following ice-sheet deglaciation (Ballantyne et al., 2014a, 2014b).

\section{The Sgriob na Caillich medial moraine}

The Sgriob na Caillich medial moraine (Figures 1-3) consists of two to four parallel belts of quartzite boulders that extend northwestwards from $450 \mathrm{~m}$ OD at the western footslopes of Beinn an Oir to within $300 \mathrm{~m}$ of the present coastline at $\sim 30 \mathrm{~m}$ OD. At its seaward end the boulder belts are truncated by a low bluff and a wide marine terrace, both of which have been eroded in till. The terrace represents the local Lateglacial marine limit at $\sim 26.9 \mathrm{~m}$ OD. The junction between the boulder belts and the till platform is occupied by a small lochan (Loch na Sgrioba) that is impounded on its seaward margin by a $\sim 300 \mathrm{~m}$ long shingle ridge with a crest altitude of 30.7-31.4 m OD. Although the boulder belts descend gradually northwestwards along most of their length, over a distance of $320 \mathrm{~m}$ they rise $30 \mathrm{~m}$ up a reverse slope to cross the low bedrock knoll of Cnoc na Sgrioba $(358 \mathrm{~m})$. In planform the main boulder belts are almost straight for most of their length (Figure 1), but near their source at the foot of Beinn an Oir the boulder deposits fan out towards the SW flank of the mountain (Figure 2).

Along much of their length, the boulder belts rise less than a metre above the adjacent terrain, forming low, broad, uneven ridges, nowhere more than $2.5 \mathrm{~m}$ high, and separated by boulderstrewn bands of ericaceous vegetation (Figure 3). The overall width of the boulder belts ranges from about $90 \mathrm{~m}$ to $170 \mathrm{~m}$ except where they fan out at their upslope source, and intervening vegetated bands nowhere exceed $50 \mathrm{~m}$ in width. The boulders within the boulder belts and scattered over the intervening vegetated areas are typically $0.2-1.3 \mathrm{~m}$ long and composed of locally-derived quartzite, with very rare erratics of schist or phyllite. The boulder belts are openwork throughout their length, lacking an infill or matrix of fine material (Figure $3 \mathrm{~b}$ ). Constituent boulders are typically angular and lack the faceting and striae that characterise debris that has been modified by subglacial abrasion; moreover, many boulders are perched on top of others, indicating dumping from a supraglacial position. The average dimensions of the boulders decline slightly but irregularly with distance from the upslope source (Dawson, 1979a).

\section{Interpretation}

The remarkable linearity of the boulder belts and the angularity of the debris led Dawson (1979a) to conclude that the belts represent a medial moraine that was superimposed across the area as the last ice sheet thinned and retreated, an interpretation that has been accepted in all subsequent accounts (Dawson, 1993; Ballantyne, 1999; Benn \& Evans, 2010; Ballantyne et al., 2014b; Small et al., 2017). Dawson (1979a) attributed the source of the debris to 'sub-aerially weathered material from the slopes of Beinn an Oir' at a time when thinning of the ice sheet 
resulted in emergence of the mountain above the surface of the ice as a nunatak. This explanation, however, is inadequate to explain the huge volume of debris within the medial moraine, or why similar moraines were not formed down-ice from Beinn a'Chaolais or Beinn Shiantaidh, or indeed down-ice from the many other isolated Scottish mountains that emerged as nunataks during thinning and retreat of the last ice sheet. The apparent uniqueness of the Sgriob na Caillich moraine requires a different interpretation.

Ballantyne et al. (2014b) observed that the source area of the medial moraine on the SW flank of Beinn an Oir coincides with bedrock gullies and cliffs that they interpreted as debrisfree failure scarps: sites of former rock-slope failures where the runout debris has been removed by glacier ice. Such scarps are common in the Scottish Highlands (Ballantyne 2013; Cave \& Ballantyne 2016). That on the SW flank of Beinn an Oir is complex (Figure 4). The most prominent features are two steep bedrock gullies that converge downslope from 750-780 m near the summit of the mountain to $\sim 570 \mathrm{~m}$, where they meet the crest of a postglacial talus accumulation; both gullies are $\sim 70-80 \mathrm{~m}$ wide, $\sim 20-30 \mathrm{~m}$ deep and bounded on both sides by steep rock scarps. The volume of the two gullies implies loss of at least $200,000 \mathrm{~m}^{3}(\sim 0.52 \mathrm{Mt})$ of rock. South of the gullies a cliff up to $60 \mathrm{~m}$ high and cut by a third smaller rock gully descends obliquely southwards from $610 \mathrm{~m}$ to $500 \mathrm{~m}$. Whether these failure scarps represent the site of a single catastrophic rockslide or a series of smaller rockfalls or rock-slope failures cannot be determined, but the occurrence of these features resolves the conundrum of explaining the huge volume of coarse angular quartzite debris that forms the moraine. It appears that emergence of the higher parts of Beinn an Oir from the thinning ice cover was succeeded by one or more substantial rockfalls or rockslides onto the ice-sheet surface, and ice converging from both flanks of the emerging nunatak carried the debris supraglacially to (and possibly beyond) the present coastline; subsequent thinning and retreat of the ice then deposited the debris to form the longest and most iconic medial moraine in Scotland.

The subdivision of the moraine along most of its length into two dominant boulder belts (Figures 1 and 3) may have resulted from differential ablation of the downwasting ice surface. During ice retreat, the adjacent debris-free ice is likely to have melted more rapidly than the debris-covered belt, so that the latter formed one (or locally more) steep-sided, ice-cored, debriscovered ridges on the thinning glacier surface (Anderson, 2000), ultimately causing much of the debris to roll or slide off the ridge or ridges to form parallel belts of boulders that were draped over the terrain as the ice margin retreated. If this was the case, the moraine can be regarded as representing a hybrid between the 'avalanche type' (landslide-sourced) and 'ablation dominated' classes of medial moraine identified by Eyles and Rogerson (1978).

\section{The age of the moraine}

Dawson (1979a) argued that seaward truncation of the boulder belts by a high Lateglacial shoreline implied that the moraine must have been deposited during retreat of the last ice sheet. Five samples chiselled from boulders on different parts of the moraine have yielded cosmogenic

${ }^{10} \mathrm{Be}$ exposure ages of $15.0 \pm 1.1 \mathrm{ka}, 16.5 \pm 1.1 \mathrm{ka}, 16.8 \pm 1.0 \mathrm{ka}, 16.8 \pm 1.1 \mathrm{ka}$ and $17.6 \pm 1.2 \mathrm{ka}$ (Ballantyne et al., 2014b; Small et al., 2017). Collectively, these give an uncertainty-weighted mean age of $16.6 \pm 0.8 \mathrm{ka}$, or $16.7 \pm 0.8 \mathrm{ka}$ if the youngest and oldest ages are excluded. This 
date represents not only the age of moraine deposition, but also the approximate timing of deglaciation of western Jura, and is consistent with that established for ice-sheet retreat in neighbouring areas (Small et al., 2017). It is likely that the rock-slope failure(s) on Beinn an Oir that fed the moraine probably occurred no more than a century or two prior to $\sim 16.6 \mathrm{ka}$.

\section{Wider implications}

Mapping of submarine bedforms and recessional moraines in the Sound of Jura to the east and the offshore shelf west of Jura indicates that the margin of the last ice sheet underwent oscillatory retreat towards its source areas to the northeast (Dove et al., 2015). The northwesterly alignment of the Sgriob na Caillich moraine, however, implies that at this locality the retreating ice margin withdrew southeastwards towards the Paps of Jura after making landfall at the coastline. This apparent anomaly appears to imply that as the main ice sheet margin withdrew to the northeast, a residual ice cap was stranded on Jura, with radial movement of ice from an ice divide located near the highest ground. This interpretation is supported the evidence of raised shorelines: a shoreline older than that which marks the marine limit at Loch na Sgrioba occurs along the coasts of northern Islay and NW Jura, implying that these areas were deglaciated by northeastwards retreat of the last ice sheet at a time when the coastline of SW Jura was still occupied by glacier ice (Dawson, 1979b, 1982). The alignment of the moraine ridges near Loch an t-Siob is also consistent with this interpretation, as they imply pulsed retreat of a residual ice mass toward the col separating Beinn a'Chaolais from Beinn an Oir.

Although the Sgriob na Caillich medial moraine is unique in Scotland in terms of its length and clarity, it is likely that landslide-sourced medial moraines and erratic trains occur elsewhere in the Highlands and Hebrides but have escaped identification. TCN dating of catastrophic rockslope failures have shown that some occurred very soon after deglaciation (Ballantyne et al., 2014a), so it is likely that others occurred when glacier ice was still present in adjacent valleys. The abundance of debris-free landslide scarps in the Highlands and Hebrides (Ballantyne 2013; Cave and Ballantyne 2016) also suggests that landslides onto glacier ice were not unusual, particularly during the Loch Lomond Stade $(\sim 12.9-11.7 \mathrm{ka})$ when numerous nunataks and mountain ridges protruded above the surface of icefields and valley glaciers. Many large lateral and end moraines that delimit the extent of Loch Lomond Stadial glaciers owe their dimensions, at least in part, to entrainment of rockfall and rockslide debris (Benn, 1989; Ballantyne et al., 2016b), and Benn et al. (2016) have described medial moraines (boulder belts) and erratic trains on Skye that were apparently fed by rockfall debris, though the sources of such debris remain to be identified. It therefore seems likely that the landslide-sourced Sgriob na Caillich moraine is not 'unique' in Scotland, but certainly the most striking representative of a family of landforms that awaits further identification and documentation.

\section{Conclusion}

Although the origin of the boulder belts of the Sgriob na Caillich as a medial moraine has been unchallenged for over four decades and is widely cited, the apparent uniqueness of this landform in a Scottish context can apparently only be explained in terms of one or more rockslope failures onto the ice surface after emergence of Beinn an Oir as a nunatak during ice downwastage. This interpretation accounts for the huge volume of openwork quartzite debris in 
the moraine, the angularity of the debris, and the origin of the moraine at the SW flank of Beinn an Oir. The narrowness of the boulder belts reflects converging ice flow from both sides of the mountain, and the arrangement of parallel boulder belts may reflect redistribution of debris due to differential ablation on the thinning and retreating ice surface. Deposition of the moraine at $\sim 16.6 \mathrm{ka}$ is consistent with the timing of deglaciation in this sector, but the alignment of the moraine athwart the direction of regional ice-margin retreat appears to indicate stranding of a residual ice mass on Jura following ice-sheet retreat northeastwards along the adjacent shelf.

\section{Access information}

There are regular ferry crossings from Port Askaig on Islay to Feolin on the west coast of Jura (https://www.argyll-bute.gov.uk/port-askaig-islay-feolin-jura-ferry-timetable). From Feolin an estate track leads north to Cnocbreac [NR 449730]. From here two tracks lead to a ford at [NR 479744], and a single track continues NE towards a waterfall at [NR 586746] giving a good view of the failure scars on Beinn an Oir. Continue NW for $1 \mathrm{~km}$ to reach the proximal end of the moraine [NR 491751] and follow the moraine to its terminus at Loch na Sgrioba [NR 775771]. The most interesting return journey follows the coast, then the estate track. The circuit from Feolin involves a walk of about $27 \mathrm{~km}$, though a mountain bike can be used on the estate tracks. Good weather is essential. Alternatively, the Sgriob na Caillich moraine and its source landslide scar can be visited with considerably less effort on Google Earth.

\section{Acknowledgements}

We thank Graeme Sandeman (University of St Andrews) for preparing Figures 2 and 3.

\section{Disclosure statement}

No potential conflict of interest was reported by the authors.

\section{References}

Anderson, R. S. (2000) A model of ablation-dominated medial moraines and the generation of debris-mantled glacier snouts. Journal of Glaciology, 46, 459-469.

Anderton, R. (1977) The Dalradian rocks of Jura. Scottish Journal of Geology, 13, 135-142.

Anderton, R. (1985) Sedimentation and tectonics in the Scottish Dalradian. Scottish Journal of Geology, 21, 407-436.

Ballantyne, C. K. (1999) Maximum altitude of Late Devensian glaciation on the Isle of Mull and Isle of Jura. Scottish Journal of Geology, 35, 97-106.

Ballantyne, C. K. (2013) Lateglacial rock-slope failures in the Scottish Highlands. Scottish Geographical Journal, 129, 67-84.

Ballantyne, C. K., Benn, D. I., Bradwell, T. \& Small, D. (2016a) The glacial history of the Isle of Skye 1: The last ice sheet. In C. K. Ballantyne \& J. J. Lowe (Eds.), The Quaternary of Skye (pp. 12-22). London: Quaternary Research Association. 
Ballantyne, C. K., Benn, D. I. \& Small, D. (2016b) The glacial history of the Isle of Skye 2: The Loch Lomond Readvance. In C. K. Ballantyne \& J. J. Lowe (Eds.), The Quaternary of Skye (pp. 23-40). London: Quaternary Research Association.

Ballantyne, C. K. Sandeman, G. F., Stone, J. O. \& Wilson, P. (2014a) Rock-slope failure following Late Pleistocene deglaciation on tectonically stable mountainous terrain. Quaternary Science Reviews, 86, 144-157.

Ballantyne, C. K., Wilson, P., Gheorghiu, D. \& Rodés, À. (2014b) Enhanced rock-slope failure following ice-sheet glaciation. Earth Surface Processes and Landforms, 39, 900-913.

Benn, D. I. (1989) Debris transport by Loch Lomond Readvance glaciers in northern Scotland: basin form and the within-valley asymmetry of lateral moraines. Journal of Quaternary Science, 4, 243-254.

Benn, D. I. \& Evans, D. J. A. (2010) Glaciers and Glaciation. $2^{\text {nd }}$ Edition. Hodder, London.

Benn, D. I., Bradwell, T. \& Owen, L. A. (2016) Glacial landforms and deposits. In C. K. Ballantyne \& J. J. Lowe (Eds.), The Quaternary of Skye (pp. 41-56). London: Quaternary Research Association.

Bennett, M. R. \& Glasser, N. F. (2009) Glacial Geology: Ice Sheets and Landforms. $2^{\text {nd }}$ Edition. Wiley-Blackwell, Chichester.

Callard, S. L., Ó Cofaigh, C, Benetti, S., Chiverrell, R. C., Van Landeghem K. J. J., Saher, M. H., Gales, J. A., Small, D., Clark, C. D., Livingstone, S. J., Fabel, D. \& Moreton, S. G. (2018) Extent and retreat history of the Barra Fan Ice Stream offshore western Scotland and northern Ireland during the last glaciation. Quaternary Science Reviews, 201, 280-302.

Cave, J. A. S. \& Ballantyne, C. K. (2016) Catastrophic rock-slope failures in NW Scotland: Quantitative analysis and implications. Scottish Geographical Journal, 132, 185-209.

Dawson, A. G. (1979a) A Devensian medial moraine on Jura. Scottish Journal of Geology, 15, $43-48$.

Dawson, A. G. (1979b) Raised shorelines of Jura, Scarba and NE Islay Unpublished PhD Thesis. University of Edinburgh.

Dawson, A. G. (1982) Lateglacial sea-level changes and ice-limits in Islay, Jura and Scarba, Scottish Inner Hebrides. Scottish Journal of Geology, 18, 253-265.

Dawson, A.G. (1993) West coast of Jura. In J. E. Gordon \& D. G. Sutherland (Eds) Quaternary of Scotland. Geological Conservation Review Series, 6 (pp. 383-388). Peterborough: Joint Nature Conservation Committee.

Deline, P., Hewitt, K., Reznichenko, N. \& Shugar, D. (2015) Rock avalanches onto glaciers. In Shroder, J. F. \& Davies, T. R. H. (Eds.) Landslide Hazards, Risk and Disasters (pp. 263319). Amsterdam: Elsevier.

Dove, D., Arosio, R., Finlayson, A., Bradwell, T. \& Howe, J. A. (2015) Submarine glacial landforms record Late Pleistocene ice-sheet dynamics, Inner Hebrides, Scotland. Quaternary Science Reviews, 123, 76-90.

Evans, D. J. A. \& Twigg, D. R. (2002) The active temperate glacial landsystem: a model based on Breidermerkurjökull and Fjallsjökull, Iceland. Quaternary Science Reviews, 21, 21432177.

Eyles, N. \& Rogerson, R.J. (1978) A framework for the investigation of medial moraine formation: Austerdalsbreen, Norway, and Berendon Glacier, British Columbia, Canada. Journal of Glaciology, 20, 99-113. 
Hambrey, M. J. \& Glasser, N. F. (2003) The role of folding and foliation development in the genesis of medial moraines: examples from Svalbard glaciers. Journal of Geology, 111, 471485 .

Jackson, L. (2017) The Foothills erratics train region. In O. Slaymaker (Ed.) Landscapes and Landforms of Western Canada (pp. 157-165). Switzerland: Springer International Publishing.

Sissons, J. B. (1977) The Loch Lomond Readvance in the Northern Mainland of Scotland. In J. M. Gray \& J. J. Lowe (Eds) Studies in the Scottish Lateglacial Environment (pp. 45-59). Oxford: Pergamon.

Small, D., Benetti, S., Dove, D., Ballantyne, C. K., Fabel, D., Clark, C. D., Gheorghiu, D. M., Newall, J. \& Xu, S. (2017) Cosmogenic exposure age constraints on deglaciation and flow behaviour of a marine-based ice stream in western Scotland. Quaternary Science Reviews 167, 30-46.

Small, D., Rinterknecht, V., Austin, W. E. N., Fabel, D., Miguens-Rodriguez, M. \& Xu, S. (2012) In situ cosmogenic exposure ages from the Isle of Skye, northwest Scotland: implications for the timing of deglaciation and readvance from 15 to 11 ka. Journal of Quaternary Science, 27, 150-158.

Small, R. J. (1987) Englacial and supraglacial sediment: transport and deposition. In A. M. Gurnell \& M. J. Clark (Eds), Glaciofluvial Sediment Transfer: An Alpine Perspective (pp. 111-145). Chichester: Wiley.

Small, R. J., Clark, M. J. \& Cawse, T. J. P. (1979) The formation of medial moraines on Alpine glaciers. Journal of Glaciology 22, 43-52.

Smiraglia, C. (1989) The medial moraines of Ghiacciaio dei Forni, Valtellina, Italy: morphology and sedimentology. Journal of Glaciology, 35, 81-84.

Vere, D. M. \& Benn, D. I. (1989) Structure and debris characteristics of medial moraines in Jotunheimen, Norway: implications for moraine classification. Journal of Glaciology, 35, $276-280$ 


\section{Captions to Figures}

Figure 1. Google Earth ${ }^{\mathrm{TM}}$ oblique image, looking SE towards the Paps of Jura. The Sgriob na Caillich medial moraine is represented by the light-coloured parallel belts of boulders that extends from the foot of Beinn an Oir in the background to Loch na Sgrioba in the foreground.

Figure 2. The Paps of Jura and the Sgriob na Caillich medial moraine, which extends $3.5 \mathrm{~km} \mathrm{NW}$ from the foot of Beinn an Oir to near the present coastline. Also shown are the sites of postglacial rock-slope failures.

Figure 3. The Sgriob na Caillich medial moraine. (a) The proximal section of the moraine, looking towards its source on the SW flank of Beinn nan Oir. (b) The central section of the moraine, where it rises $30 \mathrm{~m}$ to cross Cnoc na Sgrioba $(358 \mathrm{~m}$ ). Note the coarse angular nature of the debris, consistent with deposition from a supraglacial position by the retreating and thinning ice. (c) The distal section of the moraine, where it forms two low, parallel ridges that descend from Cnoc na Sgrioba towards its terminus at Loch na Sgrioba.

Figure 4. Google Earth ${ }^{\mathrm{TM}}$ oblique image of the SW face of Beinn an Oir. The two conspicuous downslope-converging bedrock gullies (arrowed) that descend from near the summit are interpreted as rockfall or rockslide failure scars, as is the bedrock cliff on the right. The talus accumulations at the foot of the slope are postglacial landforms that have accumulated since deglaciation. 


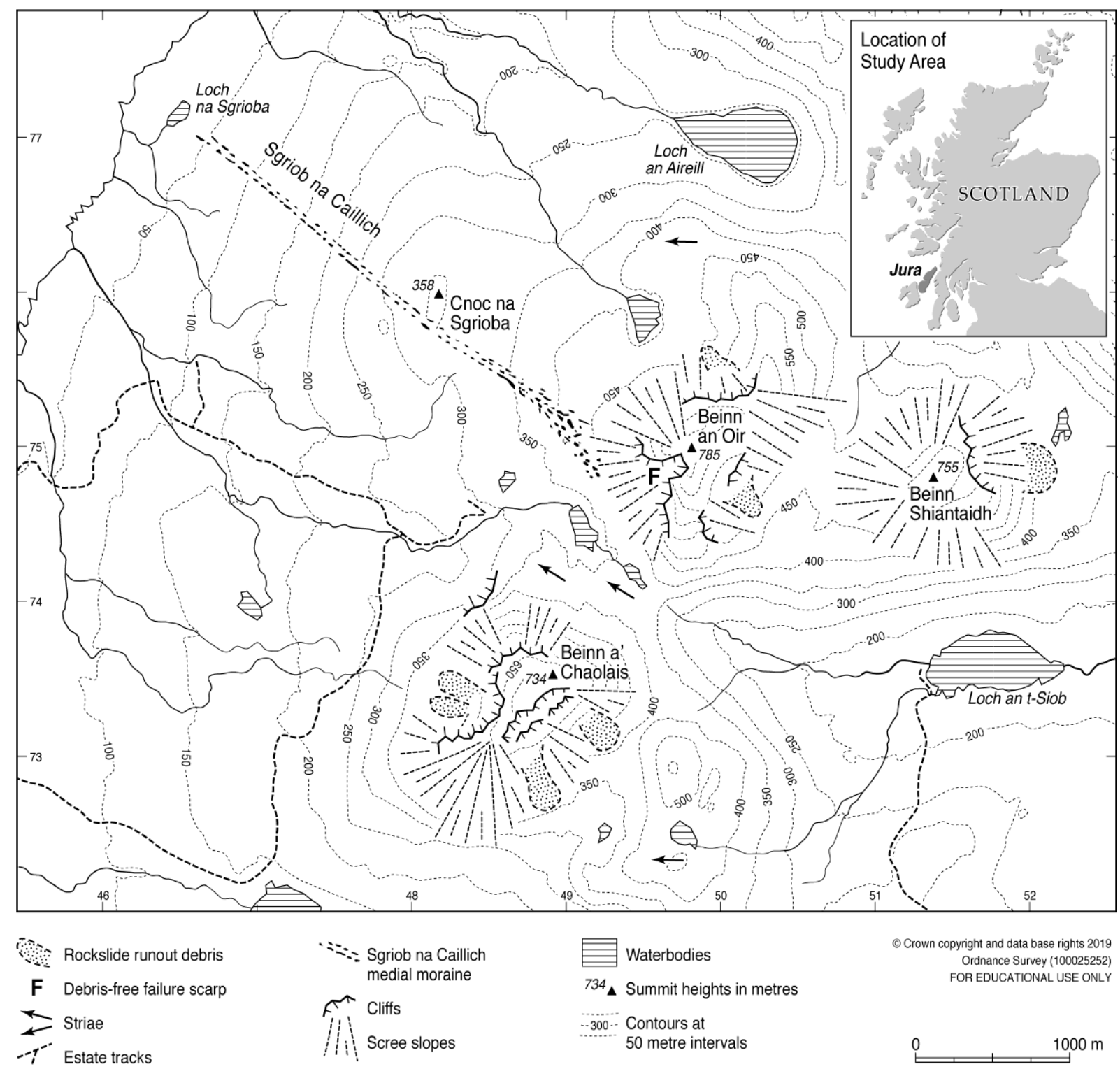

Figure 2 